\title{
Self-construction in informal settlements: A multiple-criteria decision-making method for assessing sustainability of floor slabs in Bucaramanga, Colombia.
}

Caballero, W.; Alegre, I.; Armengou, J.; Aguado, A..

\begin{abstract}
In many developing countries, a large part of the urban population lives in self-built houses located in informal settlements. Due to the basic methods and materials used in selfconstruction, most houses are only one or two stories high. As a consequence, these informal settlements tend to expand rapidly outward, occupying the safest areas first and later expanding into areas that are less suitable for construction because of steep slopes or a high risk of floods, landslides or earthquakes. This is precisely what has occurred in Bucaramanga, Colombia, the case study for the present research.
\end{abstract}

The construction of multi-story buildings is a potential solution to this problem, by reducing the extension of informal settlements. The present study reviews existing technical solutions for constructing low-cost floor slabs, one of the most critical aspects in the construction of a house, and presents a multiple-criteria decision-making method for use in prioritizing the alternatives, taking into consideration social, environmental and economic factors. These criteria for choosing between the different floor slabs also take into consideration the opinion of the inhabitants of the area, gathered through a survey administered to 772 families in 26 of Bucaramanga's informal settlements.

Keywords: self-built houses; informal settlements; multiple-criteria decision making; floor slabs, sustainability. 


\section{INTRODUCTION}

In many developing countries, a large portion of the urban population lives in informal settlements, where self-built houses are more the norm than the exception (Gilbert \& Ward, 1985; Del Mistro \& Hensher, 2009; Bredenoord \& van Lindert, 2010). Due to the rudimentary building techniques and materials used in self-built constructions, most of these houses are only one or two stories high (Ward et al., 2011). As a consequence, these settlements tend to grow rapidly in extent, occupying the safest areas first and later expanding into areas that are less suitable for construction because of steep slopes or a high risk of flood, landslides or earthquakes. In addition to risky locations, informal settlements rarely conform to any sustainability requirements aside from cost.

Building taller buildings is one potential solution, which could reduce the extension of informal settlements, thus avoiding the danger of building in locations that do not offer the minimum safety guarantees. However, building taller buildings, up to four or five stories, via selfconstruction entails some challenges because of the poor-quality materials that are usually used in this type of low-income construction and the minimal technical knowledge possessed by the informal builders. In many cases, houses built in low-income communities develop cracks soon after construction (Obeng-Odoom, 2009).

Several papers have explored different options for self-construction with a special focus on the floor slab (Imam et al. 2002; Ahmad, 2010a). The floor slab is one of the most critical aspects when it comes to constructing tall buildings, as it supports the load and transmits it to the beams and columns. Although other construction elements, such as lateral structures, beams, columns, foundations and roofs, also play an important role in the construction of buildings, the analysis performed in this study will be limited to floor slabs. However, this type of analysis, which includes the selection of floor slabs and the application of a particular multiple-criteria decision-making method, can be applied to any construction element, and the authors encourage future researchers to do so. The objective of this paper is twofold: first, to identify floor slabs that will permit inhabitants in these informal settlements to self-construct taller buildings safely and at low cost; second, to present MIVES, a multiple-criteria decision-making method that allows for a selection among alternatives by identifying the most suitable option. MIVES takes into account economic, social and environmental requirements, serving as a powerful tool for assessing the overall sustainability of different options. It responds to the call for more sustainable approaches to planning and managing landscapes worldwide (Botequilha Leitao \& Ahem, 2002). The suitability of a self-construction method is highly dependent on environmental and social 
factors such as materials available in the area, cost or local culture. As an illustrative example, this study focuses on the case of the informal settlement of Bucaramanga, Colombia.

This paper reviews commonly-used technologies with potential suitability for self-built construction in an informal settlement like Bucaramanga. First, based on the literature on housing and construction, 44 different floor slab options are identified. Next, the paper groups these structures into three different classes by similarity of techniques. Finally, the paper presents MIVES, a multiple-criteria decision-making system, as a model for assessing the suitability of the different construction techniques, emphasizing the sustainability of the resulting construction. Economic, environmental and social requirements are taken into consideration in this process.

Although the aim of this paper is to identify a floor slab construction method that allows for the self-construction of tall buildings up to four or five stories while fulfilling the necessary sustainability requirements, especially in terms of cost and safety, if the resulting proposed technical solution were unacceptable to the target population this research would remain a mere conceptual exercise. As Balchin and Stewart (2001) stated while studying self-built housing in Latin America, examining social housing outside of its context is unproductive. Thus, in order to verify the applicability of this study, it was important for the study to focus on a specific context, taking into account the preferences of the target population: in this case the inhabitants of Bucaramanga. In keeping with those purposes, the paper is organized as follows. The first part of the paper analyzes the current state of housing in Bucaramanga and explores which options would be preferred by inhabitants in terms of construction techniques and materials. This is accomplished through the use of a questionnaire, which 772 families in the area answered. The second part of the paper contains the technical analysis of different construction methods and presents the decision-making method that allows the different techniques to be compared while taking into account environmental, social and economic characteristics.

\section{CURRENT STATE OF BUCARAMANGA AND EXPECTATIONS}

Bucaramanga is an area characterized by poverty, difficulty in accessing credit and high housing need (Gilbert, 2000). It is an area with 1,065,000 inhabitants, 25\% of whom live in informal settlements, according to the Observatorio Metropolitano del Área Metropolitana de Bucaramanga (OMAMB), the government body in charge of studying urban development and housing. Bucaramanga is appropriate as a case study because it is similar to many informal settlements in Latin America with regard to the number of inhabitants, income, type of land and the major challenges it faces. 
The metropolitan area of Bucaramanga, $400 \mathrm{~km}$ north of Bogotá, Colombia, encompasses the towns of Bucaramanga, Girón, Floridablanca and Piedecuesta. It is estimated that 269,000 of the area's inhabitants live in informal settlements, in houses that do not provide the minimum living conditions (Murillo et al., 2011). According to the OMAMB, approximately $80 \%$ of the inhabitants of informal settlements live below the poverty line. Their economic situation precludes all possibility of buying a house or paying rent, so they are forced to occupy private or public land to self-build their houses in very precarious conditions. Quite frequently, families begin by using temporary materials such as plastic, wood or cardboard, and progressively move on to more permanent structures built with bricks, blocks, cement or tiles made from asbestos or zinc. Informal settlements present deficiencies not only in terms of construction materials, but also in terms of public services, such as roads or pedestrian walkways, public facilities, and health and educational services, among others.

A typical house in an informal settlement in Bucaramanga would be a one-story house with a single living space that functions as the kitchen, living room and bedroom, a separate bathroom and a small outdoor courtyard. In some cases, when families expand, and a second story is built to shelter additional family members. Appendix 1 shows some photographs of the area and the type of housing present there.

According to the Instituto de Vivienda de Interés Social de Bucaramanga (INVISBU), of the 299 hectares included in the Bucaramanga area, only 5.3\% provide the necessary conditions for housing construction. The rest of the area is characterized by geologic faults or is affected by extreme erosion or high flood risk. As such, Bucaramanga is an ideal setting for this research, since there is only a small area that is adequate for construction, and expanding vertically instead of horizontally could prevent construction in unsuitable locations.

Before proposing technical solutions for the self-construction of tall buildings (up to five stories) at low cost, it is important to know which solutions would be culturally acceptable to the target population. With this in mind, a survey was conducted among 772 families living in Bucaramanga. The survey contained questions about the social and economic situation of the family unit, as well as about their current housing and their opinions on the possibility of living in taller buildings.

\subsection{Data gathering}

One of the authors personally visited 772 of the 2,590 houses that currently stand in the 26 informal settlements within the metropolitan area of Bucaramanga. The houses were distributed across 15 informal settlements in Bucaramanga, six informal settlements located in 
Girón and five in the area of Floridablanca. Table 1 shows the number of existing houses and the number of houses that were surveyed for each settlement.

The survey was conducted at the end of 2012 and the beginning of 2013. The INVISBU supported the study and introduced the research and one of the authors to the main village leaders and representatives in order to minimize inhabitants' concerns and maximize the response rate. The survey contained descriptive questions about the families in each household, such as the number of family members, their age and occupation, and about the houses themselves, such as the materials used, number of stories and who built the house, as well as the builder's construction knowledge. Finally, the survey asked about the inhabitants' willingness to live in taller buildings.

Table 1: Number of houses surveyed with respect to the total number of houses in each settlement

\begin{tabular}{|c|c|c|c|c|c|c|c|}
\hline Informal settlement & $\begin{array}{c}\text { Total number } \\
\text { of houses }\end{array}$ & $\begin{array}{l}\text { Houses } \\
\text { surveyed }\end{array}$ & $\begin{array}{c}\text { Percentage } \\
\text { surveyed } \\
(\%)\end{array}$ & Informal settlement & $\begin{array}{l}\text { Total number } \\
\text { of houses }\end{array}$ & $\begin{array}{l}\text { Houses } \\
\text { surveyed }\end{array}$ & $\begin{array}{c}\text { Percentage } \\
\text { surveyed } \\
(\%) \\
\end{array}$ \\
\hline \multicolumn{4}{|c|}{ Bucaramanga } & \multicolumn{4}{|c|}{ Girón } \\
\hline La Torre & 19 & 13 & 68 & Mirador de San Antonio & 45 & 23 & 51 \\
\hline Bodegas & 72 & 30 & 42 & Mirador de Carrizal & 52 & 26 & 50 \\
\hline Hogar de Paso & 54 & 27 & 50 & Mi Rinconcito & 13 & 13 & 100 \\
\hline Corrales & 52 & 26 & 50 & Convivir & 300 & 43 & 14 \\
\hline La Unión & 59 & 27 & 46 & Altos de Andina & 120 & 37 & 31 \\
\hline Club Ferrocarriles & 24 & 16 & 67 & Albergue Temporal Convi & 180 & 40 & 22 \\
\hline Campamento & 14 & 11 & 79 & & & & \\
\hline Caminos de Paz I & 70 & 30 & 43 & \multicolumn{4}{|c|}{ Floridablanca } \\
\hline Caminos de Paz II & 15 & 11 & 73 & Brisas de Provenza & 226 & 40 & 18 \\
\hline Luz de Esperanza & 50 & 25 & 50 & Asohelechales & 72 & 72 & 100 \\
\hline Serviunión & 120 & 36 & 30 & Transuratoque & 60 & 28 & 47 \\
\hline Villa Mercedes & 250 & 30 & 12 & El Paramo & 324 & 44 & 14 \\
\hline Frente a la Cancha & 23 & 17 & 74 & Juan Pablo II & 20 & 20 & 100 \\
\hline Club Chimitá & 300 & 30 & 10 & \multirow{2}{*}{ Total } & \multirow{2}{*}{2590} & \multirow{2}{*}{772} & \multirow{2}{*}{$30 \%$} \\
\hline Gallineral & 56 & 56 & 100 & & & & \\
\hline
\end{tabular}

\subsection{Main results}

The outcome of the survey presents little variability, indicating that the living conditions of the different families living in the informal settlements in the Bucaramanga area are similar, as are their preferences in terms of future housing. Forty-seven percent of the houses are inhabited by families of between three and four members, whereas $27 \%$ of the houses are inhabited by between five and six people. Children under 10 years of age are present in more than $70 \%$ of the houses. Ninety percent of the adults do not have a formal job contract and make their living from informal jobs. Table 2 presents the main descriptive statistics of the results. 
Table 2 , shows that $68 \%$ of the houses were built by the family members who live in the house, with $60 \%$ of the families answering that the builder had at least a minimum knowledge of construction.

Table 2. Summary results of the survey

\begin{tabular}{|c|c|c|}
\hline Question & Mean & STD \\
\hline How many people currently live in this house? & 4.54 & 1.99 \\
\hline How many of them are less than 10 years old? & 1.32 & 1.19 \\
\hline How many of them are more than 65 years old? & 0.14 & 0.38 \\
\hline How many of them have a formal job? & 0.13 & 0.41 \\
\hline How many of them have an informal job? & 1.41 & 0.81 \\
\hline What is the total income of all the people who live in this house? (COP*) & 698,447 & 378.41 \\
\hline How long have you been living in this house? (Years) & 5.32 & 4.68 \\
\hline How many families live together in this house? & 1.09 & 0.35 \\
\hline How many unemployed people live in this house? & 0.26 & 0.50 \\
\hline Did you or someone from your family build the house? $(\mathrm{Yes} / \mathrm{No})^{* *}$ & 0.68 & 0.47 \\
\hline $\begin{array}{l}\text { Did the person who built the house have some knowledge of construction? } \\
\text { (Yes/No) }\end{array}$ & 0.60 & 0.49 \\
\hline How many rooms does this house have? & 1.63 & 0.82 \\
\hline Does this house have a toilet? (Yes/No) & 0.73 & 0.48 \\
\hline How much do you pay annually for public services? (COP) & 30,268 & 25,638 \\
\hline Is it important for you to have dividing walls in your house? (Yes/No) & 0.97 & 0.15 \\
\hline Would you like to live in a tall building (up to 5 stories)? (Yes/No) & 0.85 & 0.35 \\
\hline $\begin{array}{l}\text { Would you be happier living in an apartment than in a house if the apartment } \\
\text { were cheaper? (Yes/No) }\end{array}$ & 0.95 & 0.23 \\
\hline Would you be willing to help in the construction of the building? (Yes/No) & 0.97 & 0.18 \\
\hline Do you have any preference in terms of a higher or lower floor? ( $1-5$ stories $)$ & 2.18 & 1.21 \\
\hline How much would you be able to pay in rent? (COP) & 127,662 & 89.336 \\
\hline
\end{tabular}

${ }^{*}$ COP: Colombian peso, ${ }^{* *}$ To calculate the meand and standard deviation of Yes/No questions, answers have been transformed into a dummy variable where $\mathrm{Yes}=1$ and $\mathrm{No}=0$.

In addition to the questions outlined in Table 2, there were two open response questions, which asked the families how they had obtained the construction materials to build their current housing and whether they had any preference in terms of construction materials for their future housing. With regard to the first question, about how they obtained the construction materials for their current housing, $64 \%$ answered that they bought the materials, while $29 \%$ reported that they had bought part of the material and the rest was a gift or a donation. With regard to the preferred construction material for their future housing, $68 \%$ preferred bricks, followed by $26 \%$ who preferred concrete. Only a very small minority answered that they did not care or that they preferred other materials (1\%). 
Regarding the idea of living in taller buildings, the answers confirmed that people would be willing to live in taller buildings and that they would be willing to help in the construction if it would result in reduced costs. The preferred materials were brick or concrete, since inhabitants reported that they would provide a feeling of stability and strength.

\section{CONSTRUCTION OPTIONS}

A detailed review of the literature about low-cost roofing and floor options in the JSTOR, CYTED and Google Scholar databases reported nearly 100 different options (Caballero, 2014). Although all the construction systems were identified as suitable for low-cost construction, not all fulfilled the conditions required for self-construction. The criteria for narrowing the initial list were as follows:

i. To facilitate self-construction, the resulting construction element should not weigh more than $70 \mathrm{~kg}$, in order to be manageable by two adults.

ii. The construction elements should not require specialized knowledge, so as to facilitate self-construction by a relatively uneducated population.

iii. The construction elements should not require the use of complex machinery.

iv. The construction elements must use raw materials that are easily available to the local population: in this case, inhabitants of the informal settlements of Bucaramanga.

v. The construction materials must be acceptable to the local population. According to the extensive survey conducted, materials such as soil, bamboo or plastic have very low local acceptance. This criterion eliminated some materials from the list that have shown to be appropriate for self-construction in difficult terrains (Clarke, 2010) or seismic areas (Li and Dong, 2012).

Using these criteria, a total of 44 different construction methods and structural elements used in different countries in low-cost self-construction were identified from the initial search results. These methods are listed in Table 3. 
Table 3. List of construction elements suitable for self-built, low-cost construction in seismic soils

\begin{tabular}{|c|c|c|c|c|}
\hline$\#$ & Type & Name & Country & Reference \\
\hline 1 & \multirow{11}{*}{$\begin{array}{l}\text { Flat- } \\
\text { topped } \\
\text { joist }\end{array}$} & T joist & Chile & Mora, C. \& Andrés, R. (2003). \\
\hline 2 & & TT joist & Chile & $\begin{array}{l}\text { Santibáñez, R. A. U. \& Andrés, } \\
\text { R. (2004) }\end{array}$ \\
\hline 3 & & TT joist & India & Imam, N. et al. (2002) \\
\hline 4 & & Sluice joist & Italy & Mattone, R. (1990) \\
\hline 5 & & Sluice joist & India & Imam, N. et al. (2002) \\
\hline 27 & & Sluice joist & Cuba & Gálligo, P.L. (2005) \\
\hline 6 & & $\mathrm{C}$ joist & $\begin{array}{l}\text { Trinidad and } \\
\text { Tobago }\end{array}$ & Clarke, R. P. (2010) \\
\hline 9 & & C joist & Oman & Hago, A.W. et al. (2005) \\
\hline 7 & & Hollow box joist & Chile & $\begin{array}{l}\text { Pinto Vergara, A. S. \& Arnés } \\
\text { Valencia, H. (2005) } \\
\end{array}$ \\
\hline 10 & & Hollow box joist & Philippines & Abaloso, R. et al. (2009) \\
\hline 11 & & L joist & India & $\begin{array}{l}\text { Jagannath, V., \& Chandra } \\
\text { Shekar, U. (1989) }\end{array}$ \\
\hline 12 & \multirow{6}{*}{$\begin{array}{l}\text { Joist filler } \\
\text { block }\end{array}$} & Cylindrical ferro-cement panels & Argentina & Imam, N. et al. (2002) \\
\hline 13 & & Trapezoidal ferro-cement element & India & Desayi, P. et al. (1982) \\
\hline 14 & & Omega joist & Chile & Pezo, J. L. V., \& Luís, J. (2004) \\
\hline 20 & & HEGO system & Mexico & \multirow{4}{*}{ Gálligo, P.L. (2005) } \\
\hline 23 & & LAM system & Cuba & \\
\hline 28 & & Batea system & Argentina & \\
\hline 8 & \multirow{27}{*}{$\begin{array}{l}\text { Joist and } \\
\text { slab }\end{array}$} & U joist & Brazil & \\
\hline 15 & & Ferro-cement Joist & Pakistan & Ahmad, S.F. (2010b) \\
\hline 16 & & Composite Ferro-cement Slab & Egypt & Aboul-Anen, B. et al. (2009) \\
\hline 17 & & Ferro-cement Slabs & India & Dhasarathan, A. et al. (2012) \\
\hline 18 & & Ferro-cement panel for composite masonry & Malaysia & Yardim, W. T et al. (2008) \\
\hline 19 & & Ferro-cement brick composite slab panel & Malaysia & Thanoon, W.A. et al. (2010) \\
\hline 21 & & Small slab & Chile & \begin{tabular}{|l}
$\begin{array}{l}\text { Castillo, A.A.T. \& Arnés } \\
\text { Valencia, H. (2006) }\end{array}$ \\
\end{tabular} \\
\hline 22 & & joist+panel & Pakistan & $\begin{array}{l}\text { Waliuddin, A. M., \& Ismail, M. } \\
\text { S. (1995). }\end{array}$ \\
\hline 24 & & joist + small slab & Cuba & \multirow{3}{*}{ Gálligo, P.L. (2005) } \\
\hline 25 & & DOMOZED system & Peru & \\
\hline 26 & & joist+small slab & Portugal & \\
\hline 29 & & Precast Reinforced Brick Panels & India & Rinku, T. \& Devit, V. (2009 \\
\hline 30 & & Reinforced Masonry Panels & Portugal & Barros, J.A. et al. (2006) \\
\hline 31 & & Sancocho system & Venezuela & \\
\hline 32 & & Concrapego system & Venezuela & Gálligo, P.L. (2005) \\
\hline 33 & & Sidepanel system & Venezuela & \multirow{12}{*}{ Cansario, M. (2005) } \\
\hline 34 & & Triditec system & Mexico & \\
\hline 35 & & Tridipanel system & Austria & \\
\hline 36 & & Pentawall system & Argentina & \\
\hline 37 & & Muroplac system & Colombia & \\
\hline 38 & & Panel Monolite Ondulado & Chile & \\
\hline 39 & & Panel Simple Fridulsa & Uruguay & \\
\hline 40 & & Panel W with expanded polystyrene & Mexico & \\
\hline 41 & & Panel Vitrak & Chile & \\
\hline 42 & & Panel Covintec Qualy Panel & Mexico & \\
\hline 43 & & Electro panel & Guatemala & \\
\hline 44 & & Panel Simple MDUE (M2) & Italy & \\
\hline
\end{tabular}

These 44 construction elements can be classified into three groups depending on their shape: flat-topped joist, joist filler block and joist and slab. In each of the groups, the different options are similar in terms of shape and material used but they are heterogeneous in length or width. As such, the different structures within each group present different weights and 
resistances. To provide a clearer understanding of the group classification and the differences between the three groups, Figure 1 shows a schematic of one example from each group.

Figure 1. Structural elements selected

Flat-topped joist type. \#1. Mora, C. \& Andrés, R. (2003).
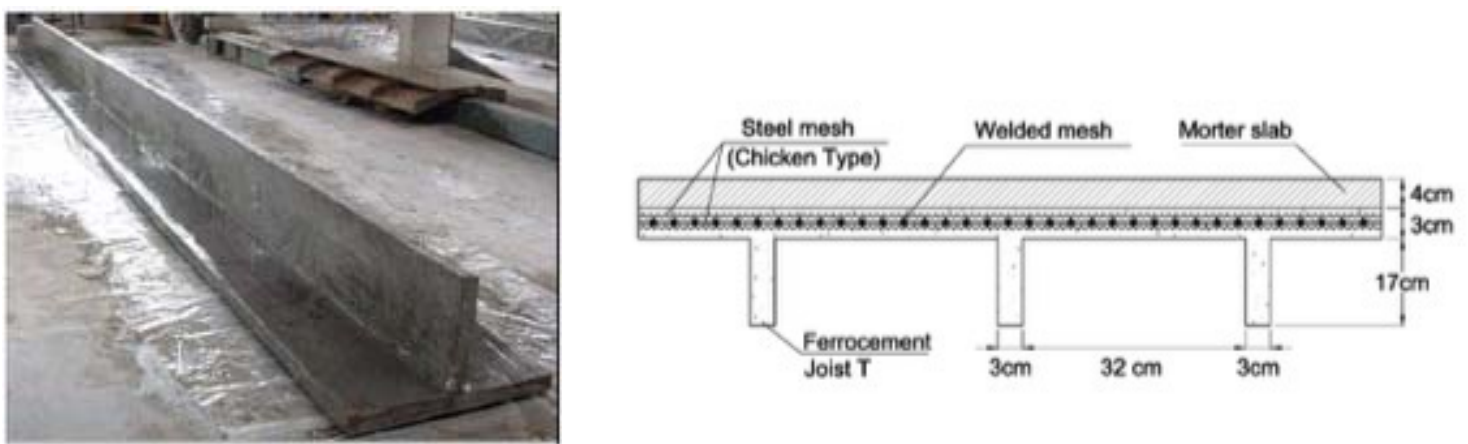

Joist filler block type. \#20. Gálligo, P.L. (2005).
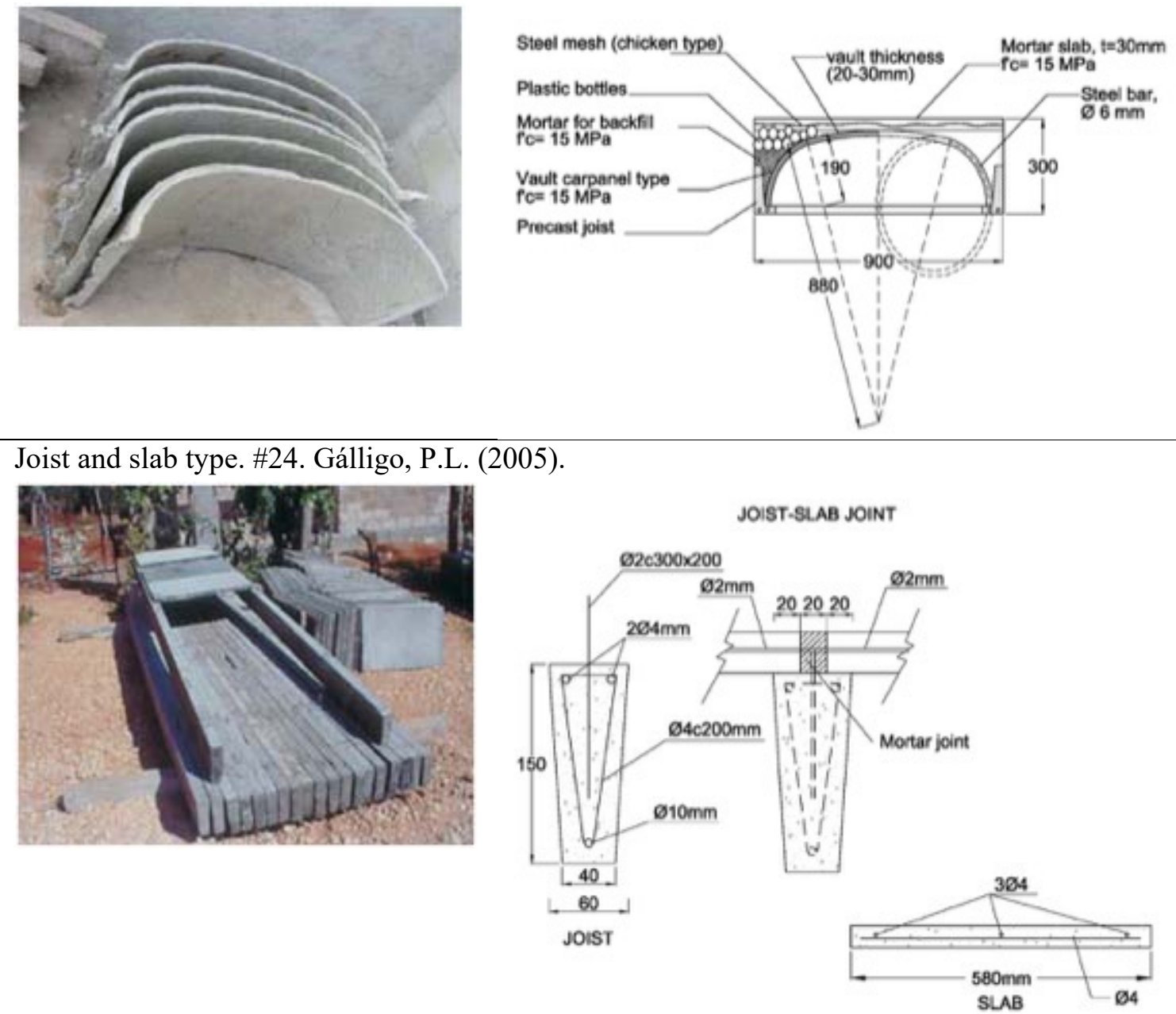

\section{MIVES DECISION-MAKING METHODOLOGY}

\subsection{MIVES general characteristics}


From the previous section, it is clear that there are three basic types of low-cost floor slabs that are appropriate for self-construction due to their weight, the knowledge and machinery required for their use, and the fact that they employ materials that are locally available and culturally acceptable. These types are either flat-top joists, joist filler blocks or joist and slabs all of them using ferrocement. The length and width of the floor slab will depend on the size of house to be built.

All of the three aforementioned construction methods are technically suitable but which one is best in terms of sustainability is still to be known. That is, which method is more appropriate, taking into account social, economic and environmental criteria? To answer that, this study uses a multiple-criteria decision making method called MIVES. MIVES is a decisionmaking method, developed relatively recently for the purpose of evaluating the sustainability of industrial buildings and constructions (San José et al., 2007, San José and Garrucho, 2010, Cuadrado et al., 2012).

MIVES has gained popularity in the past 10 years and has been applied in numerous construction projects of different types: civil engineering infrastructure (Ormazabal et al., 2012), schools (Pons and Aguado, 2012), pipes (de la Fuente et al., 2016a), wind-turbine systems (de la Fuente et al., 2016b) and others (del Caño et al., 2012; Pons et al., 2016). MIVES is used to compare general structures and normative frameworks (Aguado et al., 2012), as well as to compare specific aspects of structures, such as pillars and beams, or the resistance of certain construction elements (Pons and de la Fuente, 2013).

More recently, MIVES has been applied in other contexts, which has demonstrated the versatility of this decision-making methodology. These new applications of MIVES include: construction (Casanovas et al., 2014), electricity generation (Barros Cartele, et al., 2015), site location for postdisaster temporary housing (Hosseini et al., 2016a and 2016b), local policy (Pujadas et al., 2017) and ethics (Melé and Armengou, 2016). Van Kamp et al. (2003) stressed the importance of finding a tool to evaluate multidimensional aspects of urban planning. As shown by the previous examples, MIVES is a valid option for compare the three groups of technically viable floor slab proposals.

The main characteristics of MIVES, which distinguish it from other decision-making methodologies, are the following:

- Use of a requirements tree, usually divided into three levels: requirements, criteria and indicators. Requirements and criteria are used to structure the decisions and considerations. Indicators are the tools used to measure the criteria properly. 
- Possibility of comparing alternatives that may be homogeneous but also heterogeneous. In the case of heterogeneous alternatives, a preliminary homogenization phase is required (Pardo \& Aguado, 2015; Pardo \& Aguado, 2016). This characteristic is particularly relevant because, in addition to comparing similar alternatives, it allows MIVES to compare alternatives that are quite different from one another.

- Use of continuous value functions (Alarcón, 2011) to detail the indicators. This is an advantage of MIVES with respect to other multiple-criteria decision-making methods that use discontinuous functions. With the use of continuous functions, MIVES achieves a higher degree of precision.

- Use of an analytical hierarchy process (AHP) (Saaty, 1980, 2006) to determine the weights of the requirements, criteria and indicators specified in the requirements tree. This is especially useful when the decision trees are complex. This does not come into play in the current paper, since the decision tree is quite simple.

- Possibility of introduce a deterministic or probabilistic approach (del Caño, et al., 2012) or a diffuse mathematics approach (del Caño, et al., 2016) to assign values to the indicators. The fact that MIVES offers an array of different approaches provides the decision maker with more flexibility, which is not possible using other decision-making methodologies.

- High degree of involvement of the decision maker in the decision and also collaboration from experts in the definition of the different weights and values. Experts and decision makers not only build the requirement tree, they also define which criteria are to be rejected or which indicators are not representative.

The main initial phase of the MIVES method consists of defining the requirements tree. The requirements tree is the most important part of the process, as it will be the foundation for all the subsequent calculations. The requirements tree must be coherent and complete, and it must represent all the main decision criteria under consideration. In the case of the present research, the three most important requirements are the economic, environmental and social contexts. The identification of the requirements and the subsequent criteria and indicators come from a review of the literature as well as from experts in the area.

Cost is the main driver taken into account by the inhabitants of informal settlements, and therefore the economic criteria - both in terms of the direct cost of construction and maintenance costs are a critical factor. Environmental criteria area also important as well as social requirements, such as compliance with safety standards and adaptability to changes. 
The three requirements (economic, environmental and social) have been further divided into six criteria and nine indicators as reflected in Table 4 . The tree structure is based on previous applications of the MIVES methodology in similar cases cited previously in this paper (i.e.: Ormazabal et al., 2012; Pons and Aguado, 2012; Pons and de la Fuente, 2013; Casanovas et al., 2014; Barros Cartele et al., 2015; Hosseini et al., 2016a and 2016b; de la Fuente et al., 2016a and 2016b). The tree structure, including requirements, criteria, indicators and weights, has been adapted to the current case relying on the experience of experts in the field of engineering and construction.

Table 4. Requirements tree

\begin{tabular}{lll}
\hline Requirement & Criteria & Indicator \\
\hline \hline $\begin{array}{l}\text { R1 Economic } \\
\text { Option A: 80\% }\end{array}$ & $\mathrm{C}_{1}$ Direct cost (75\%) & $\mathrm{I}_{1}$ Direct Cost (100\%) \\
\cline { 2 - 3 } Option B: 33\% & $\mathrm{C}_{2}$ Maintenance (25\%) & $\mathrm{I}_{2}$ Maintenance (100\%) \\
\hline & & $\mathrm{I}_{3}$ Material consumption (33\%) \\
R2 Environmental & $\mathrm{C}_{3}$ Construction (80\%) & $\mathrm{I}_{4}$ Energy consumption (33\%) \\
$\begin{array}{l}\text { Option A: } 10 \% \\
\text { Option B: 33\% }\end{array}$ & & $\mathrm{I}_{5} \mathrm{CO}_{2}$ emissions (33\%) \\
\cline { 2 - 3 } & & \\
\hline R3 Social & $\mathrm{C}_{4}$ Deconstruction (20\%) & $\mathrm{I}_{6}$ Waste (100\%) \\
$\begin{array}{l}\text { Option A: } 10 \% \\
\text { Option B: 33\% }\end{array}$ & $\mathrm{C}_{5}$ Safety (65\%) & $\mathrm{I}_{7}$ During construction (40\%) \\
\cline { 2 - 3 } & $\mathrm{C}_{6}$ Adaptability to changes (35\%) & $\mathrm{I}_{8}$ Utilization $(60 \%)$ \\
\hline
\end{tabular}

The economic requirement is further divided into two criteria: direct cost and maintenance cost. The environmental requirement is also divided into two criteria, construction and deconstruction, which are measured using four indicators: material consumption, energy consumption, $\mathrm{CO} 2$ emissions and quantity of waste when deconstructed. Deconstruction has been taken into consideration because houses are frequently demolished in informal settlements, sometimes because the family has grown and a bigger house is needed, or because the family's economic situation has improved and a house with higher quality materials will be built in place of the old one. Under the social requirement, two criteria are detailed: one refers to safety, both during the construction and after the construction, and the other to re-usability. The division of the requirements into several criteria has been undertaken following the literature and taking into account advice from experts. In addition, the requirements tree was presented to the INVISBU, which agreed on the above criteria as the most critical the particular case of Bucaramanga, bearing in mind the preferences of the inhabitants as expressed in the questionnaire. 
Other criteria were considered and disregarded for different reasons. For example, resistance was a necessary condition for all the alternatives to be compared. Floor slabs that could not resist or bear the expected load of a five-story building were eliminated from the list of options from the beginning. The same is true for self-constructability: all options are apt for self-construction. Other criteria, such as construction time, were initially considered but were disregarded after some tests. A group of first-year engineering students from the Engineering School of the Universidad Santo Tomás de Bucaramanga manually built an example of each of the three representative floor slabs to verify that they were indeed possible to self-build by inexperienced people and to see whether there were significant differences in aspects such as construction time or construction complexity. No differences were found in this regard, and therefore this criterion was nondiscriminating.

Each criterion has its corresponding indicator which is used to effectively compare the alternatives. Direct cost includes the cost of materials; direct labor is not included, since the study is limited to self-construction and therefore a direct labor cost of zero is assumed. The case is the same for maintenance cost. Material consumption refers to the amount of raw materials (cement, steel, water, etc.) used. Energy consumption takes into account the electricity necessary to construct the floor slab, and $\mathrm{CO}_{2}$ emissions compares the $\mathrm{CO}_{2}$ emissions during construction of each of the different methods. Waste compares the amount of waste when de-constructing the floor slab. Safety and reusability are self-explanatory.

Following the MIVES decision-making methodology, a weight is assigned to each of the requirements. The weights given to each requirement, each criterion and each indicator establish their relative importance. Therefore, these weights adapt the general requirements tree to the specific conditions of the case study. The present paper details two examples of these weights: one that aims to represent the current perspective of the inhabitants of Bucaramanga (option A) and one that aims to mimic the perspective of a governmental agency (option B).

First, from the perspective of the inhabitants of Bucaramanga's informal settlements, based on their answers to the questionnaires, it is clear that the economic requirement is the most important for them. Thus, it is given a higher weight $(80 \%)$, whereas the remaining requirements will be secondary. The environmental requirement will be assigned $10 \%$ of the weight, and the social requirement will receive the other $10 \%$. The second perspective is that of a governmental agency. Here, environmental and social criteria are as important as the economic requirement, and therefore the weights will be equally distributed: $33 \%$ for each requirement, aligned with the Rio Declarations (UN 1992). In this paper, weights have been given by direct assignment for all requirements, criteria and indicators. However, readers who are interested in more sophisticated 
methodologies when it comes to assigning weights are invited to refer to the analytical hierarchy process (Saaty, 1988).

\subsection{Comparison of alternatives}

The value of each of the indicators $\left(\mathrm{I}_{\mathrm{i}}\right)$ may be assigned quantitatively for some of them - for example using $€ / \mathrm{m}^{2}$ to assign values to the Direct Cost indicator $\left(\mathrm{I}_{1}\right)$ - or qualitatively, like in the case of the Safety During Construction indicator $\left(\mathrm{I}_{7}\right)$.

In the present study, value functions (Alarcón et al., 2011) are used to assign a quantitative value to each of the indicators. The generic form of a value function is represented by equation 1 , which allows the sustainability associated with each indicator ( $\left.\mathrm{I}_{\text {ind }}\right)$ to be assessed by transforming the physical units into a dimensionless value between 0 and 1.

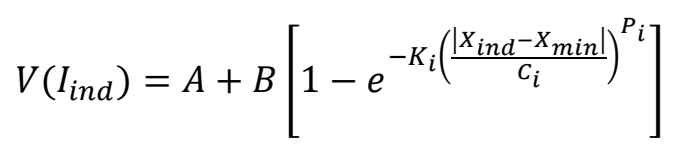

In equation $1, A$ is the value of $\mathrm{I}_{\text {ind }}$ for $\mathrm{X}_{\min }$, in this case, $0 . \mathrm{X}_{\min }$ is the minimum abscissa value in the indicator interval assessed. Thus, $X_{\max }$ is equal to 1 and $X_{\min }$ is equal to 5 for a linear decreasing function; $\mathrm{X}_{\max }$ is equal to 5 and $\mathrm{X}_{\min }$ is equal to 1 for a linear increasing function. $\mathrm{X}_{\text {ind }}$ is the abscissa value for the indicator assessed, which will move in the range 1-5. $\mathrm{P}_{\mathrm{i}}$ is a shape factor, which defines the shape of the curve (concave, convex or linear). $\mathrm{C}_{\mathrm{i}}$ approximates the abscissa at the inflexion point, and $\mathrm{K}_{\mathrm{i}}$ tends toward $\mathrm{I}_{\text {ind }}$ at the inflexion point $(\mathrm{C}=100, \mathrm{~K}=0.01$ and $\mathrm{P}=1$ for the whole set of indicators). $\mathrm{B}$ is the factor that prevents the function from exceeding the range (0-1) and also depends on the parameters $K_{i}, X_{\max }, X_{\min }$ and $C_{i}$ (de la Fuente et al., 2017).

Table 5 details the total weight of each indicator for each of the options, calculated as the weight of the requirement multiplied by the weight of the criteria and the weight of the particular indicator. Option A sets forth a scenario where the economic criterion is the most important one, mimicking the point of view of the inhabitants of informal settlements. Option B gives the same weight to each of the criteria (economic, environmental and social), mimicking the requirements of a governmental agency in designing housing policies for that area. 
Table 5. Total weights and value functions for each of the indicators

\begin{tabular}{cccccccc} 
& & & & & & \multicolumn{3}{c}{ Values for each of the } \\
& & & & & & & $\begin{array}{c}\text { Flat } \\
\text { alternatives }\end{array}$ \\
& Indicator & $\begin{array}{c}\text { Total weight } \\
\text { Option A }\end{array}$ & $\begin{array}{c}\text { Joist } \\
\text { and } \\
\text { joist } \\
\text { slab }\end{array}$ & $\begin{array}{c}\text { Joist } \\
\text { filler } \\
\text { block }\end{array}$ \\
\hline $\mathrm{I}_{1}$ & Direct cost & $60 \%$ & $25.0 \%$ & Linear decreasing & 3 & 2 & 1 \\
\hline $\mathrm{I}_{2}$ & Maintenance & $20 \%$ & $8.3 \%$ & Linear decreasing & 1 & 1 & 4 \\
\hline $\mathrm{I}_{3}$ & $\begin{array}{c}\text { Material } \\
\text { consumption }\end{array}$ & $2.6 \%$ & $8.7 \%$ & Linear decreasing & 1 & 2 & 4 \\
\hline $\mathrm{I}_{4}$ & $\begin{array}{c}\text { Energy } \\
\text { consumption }\end{array}$ & $2.6 \%$ & $8.7 \%$ & Linear decreasing & 3 & 4 & 1 \\
\hline $\mathrm{I}_{5}$ & CO2 emissions & $2.7 \%$ & $9.0 \%$ & Linear decreasing & 2 & 3 & 1 \\
\hline $\mathrm{I}_{6}$ & Waste & $2.0 \%$ & $6.6 \%$ & Linear decreasing & 1 & 2 & 3 \\
\hline $\mathrm{I}_{7}$ & $\begin{array}{c}\text { Safety during } \\
\text { construction }\end{array}$ & $2.6 \%$ & $8.8 \%$ & Linear increasing & 5 & 4 & 2 \\
\hline $\mathrm{I}_{8}$ & $\begin{array}{c}\text { Safety during } \\
\text { utilization }\end{array}$ & $3.9 \%$ & $13.3 \%$ & Linear increasing & 5 & 4 & 2 \\
\hline $\mathrm{I}_{9}$ & Re-usability & $3.5 \%$ & $11.9 \%$ & Linear increasing & 2 & 1 & 1 \\
\hline
\end{tabular}

Once the value function for each indicator has been defined, the sustainability index score for each alternative can be determined. To this end, the additive formula shown in equation (2) must be applied to each alternative. The index is a result of multiplying the weight of each alternative $\left(\mathrm{w}_{\mathrm{i}}\right)$ by its value function $(\mathrm{V})$, plotting in the value of the indicator $\left(\mathrm{x}_{\mathrm{i}}\right)$. As an example, equation 2 shows the resulting indexes for each of the alternatives. $\mathrm{N}$ is the number of indicators that belong to a single criterion.

$$
\text { Index }=\sum_{i=1}^{N}\left[w_{i} \cdot V\left(x_{i}\right)\right]
$$

(Equation 2)

In option $\mathrm{A}$, the resulting indexes ( $\mathrm{I}_{\text {flat-topped }}=0.65$ for the construction element with a flat-topped joist, $\mathrm{I}_{\mathrm{J} \text { oist and slab }}=0.75$ for the construction element with a joist and slab, and $\mathrm{I}_{\text {joist filler block }}=0.73$ for the joist filler block) are only relevant in comparison to each other, meaning that overall, taking into consideration economic requirements $(80 \%)$, environmental requirements $(10 \%)$ and social requirements $(10 \%)$, the option of a joist and slab is better than the joist filler block, and both are better than the flat-topped option.

If the weights assigned are those of option $\mathrm{B}$ - that is, giving equal weights to economic, social and environmental criteria - the indexes change $\left(\mathrm{I}_{\text {flat-topped }}=0.72, \mathrm{I}_{\text {joist and slab }}=0.61\right.$ and $\mathrm{I}_{\text {joist filler block }}$ $=0.54)$. The structural element with the flat-topped joist is then the option with the highest index, i.e., the preferred option. 


\subsection{Results}

Not surprisingly, when guided by the criteria established by option A, giving $80 \%$ of the weight to economic criteria and much less to environmental and social factors, the most expensive option, the flat-topped joist, comes out as the least preferred one. In contrast, taking a policy perspective and balancing the three requirements (economic, environmental and social) equally, as in option $\mathrm{B}$, the winning option is the flat-topped joist. This is illustrated in Figure 2. In each bar, the contribution of each criteria, economic, environmental and social, to the overall index is shown with the color code. In Option A, the joist and slab floor slab comes out as the technical solution with higher sustainability index, while in Option B, the flat-topped joist is the winner. The differences are due, as explained previously, to the different weights given to each of the criteria depending on the decision-maker criteria.

Figure 2. Comparison of sustainability indexes between options A and B.

\section{Option A}

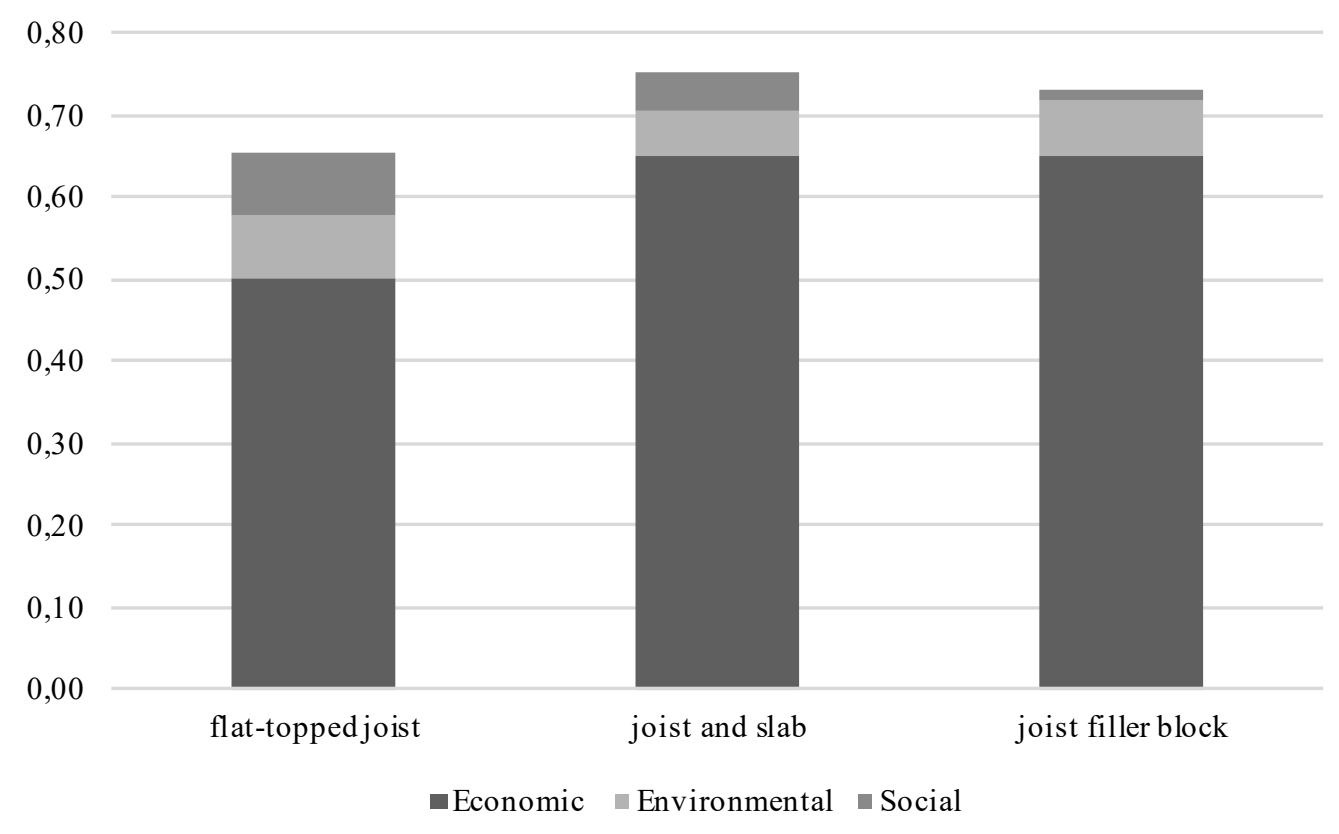




\section{Option B}

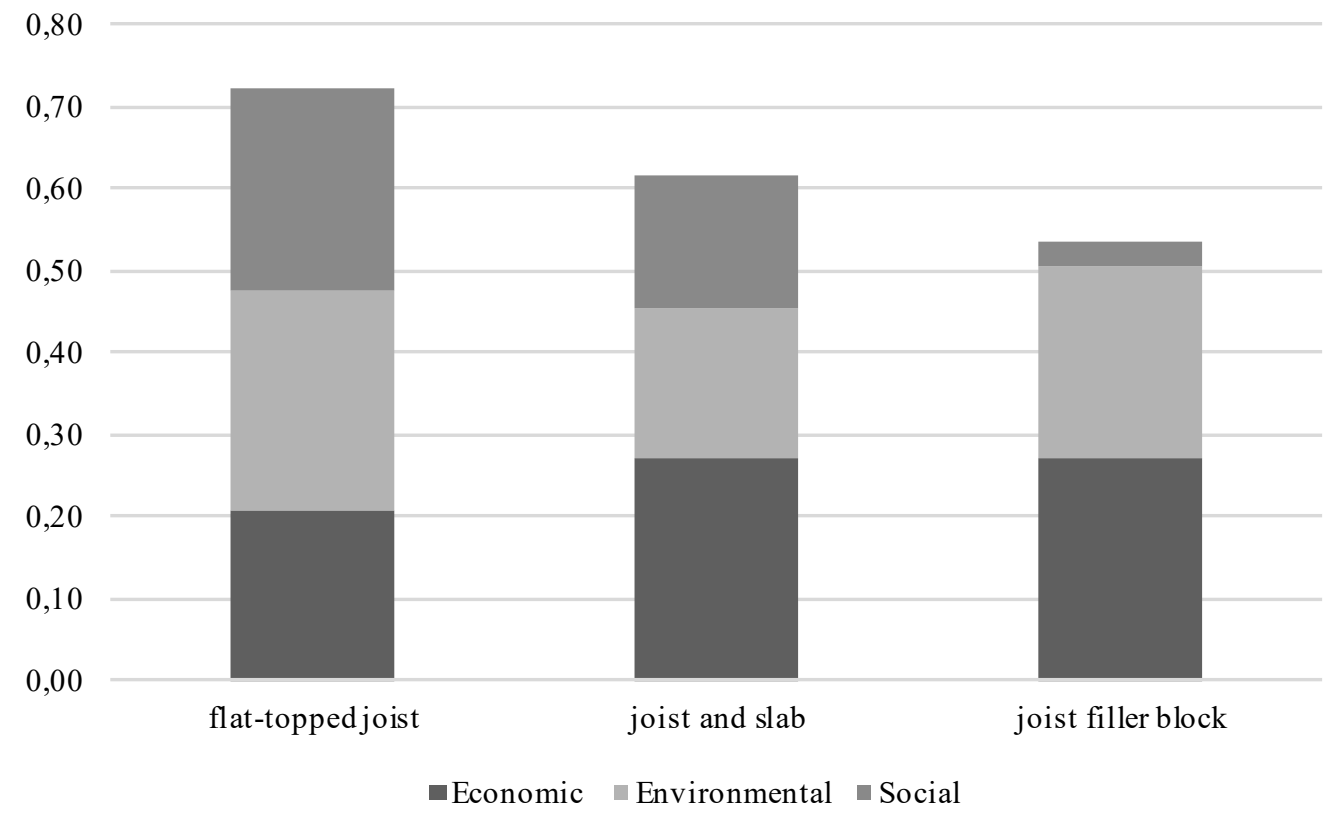

This finding emphasizes the importance of assessing the weights of each of the requirements, criteria and indicators present in the requirements tree according to the decision-making person or organization's priorities. The substantial influence of changes to the weights assigned to each criteria also suggest the value of performing a sensitivity analysis to account for all points of view and evaluate their consequences.

To check the robustness of the results, a small sensitivity analysis was performed. For option A, the weight given to the economic requirement, initially established at $80 \%$, was changed to between $70 \%$ and $90 \%$. In all cases, the joist and slab option was preferred. For option B, the weight given to the economic requirement, initially $33 \%$, was moved to between $25 \%$ and $45 \%$. In all cases, the flat-topped joist option was preferred. The sensitivity analysis could be expanded by modifying not only the weights assigned to the economic requirements but also the weights of the criteria or indicators.

\section{CONCLUSIONS}

Many people live in self-built informal settlements that do not provide the conditions of safety and comfort necessary for living. Building multi-story houses could potentially mitigate this problem. However, finding construction elements, especially floor slabs that are low cost and that can be self-built while safely supporting tall buildings, is a challenge.

This paper has identified several construction methods that could be suitable for the selfconstruction of floor slabs for tall buildings safely and at a low cost. The different methods have 
been analyzed and compared using a multiple-criteria decision-making methodology called MIVES, which has shown to be useful in differentiating among various alternatives, taking into consideration economic, social and environmental criteria.

All the construction methods identified in this paper were then classified into three groups: flattopped joist, joist filler block and joist and slab. With the help of several experts in the field, the characteristics of each group were assessed, and the groups were compared using MIVES. This method has allowed for identifying the most appropriate type of floor slab corresponding to the social need under consideration. It is also important to highlight that this paper shows that selfconstruction is possible while taking into consideration sustainability criteria such as environmental and social requirements. The main conclusions of the paper are, therefore:

- The authors identified 100 alternative low-cost floor slab construction methods in the literature. We narrowed that selection based on feasibility for self-construction. Finally, then we conducted a survey to determine the preferences of residents in the type of Latin American informal settlements under study. The result is a comprehensive list of 44 lowcost floor-slab self-construction methods acceptable to the local population.

- These 44 construction systems belong to three basic groups of construction methods: flattopped joist, joist and slab and joist filler block, all made with ferrocement. From a review of the literature, however, it is not clear which construction method is superior.

- The present paper presents a multiple-criteria decision-making method (MIVES) which, although it is applied with many simplifications, allows for an initial assessment and ranking of the alternatives proposed, taking into account not only economic criteria but also social and environmental factors.

- This paper also demonstrates the applicability of the MIVES method by using it in the case of floor slabs in the informal settlements around Bucaramanga, Colombia. An indepth survey gathered the opinion of the area's inhabitants, which was critical to situate the research in the appropriate context.

This paper is one approximation of low-cost self-construction elements, and it presents a method for establishing a multiple-criteria decision-making process that takes into account social, environmental and economic factors. Future research could expand on this investigation in the area of engineering by doing a more detailed analysis of the different options presented here and establishing more precise homogenization criteria. The research could also be expanded in the area of decision making by applying the MIVES method in other contexts. Finally, this research 
contributes to the areas of housing and construction by presenting, in a structured and organized way, a range of different floor slabs available along with a methodology to choose among them.

\section{References}

Abasolo, R., Bandivas, C., Guinita, J. V., Palen, J., Parners, E., \& Apor, G. (2009). Utilization of ferrocement as flexural building member. Student Working Paper, Xiraadman Research Center, Xavier University, Philippines, 29.

Aboul-Anen, B., El-Shafey, A., \& El-Shami, M. (2009). Experimental and analytical model of ferrocement slabs. International Journal of Recent Trends in Engineering, 1(6), 25-29.

Aguado, A., del Caño, A., de la Cruz, P., Gómez, D., \& Josa, A. (2012). Sustainability assessment of concrete structures: The EHE approach. Journal of Construction Engineering and Management. ASCE. Vol. 138 (2): 268-276. doi: 10.1061/(ASCE)CO.1943-7862.0000419.

Ahmad, S. F. (2010a). Precast ferrocement barrel shell planks as low cost roof. Challenges, opportunities and solutions in structural engineering and construction, 645-649. London: Taylor \& Francis Group.

Ahmad, S. F. (2010b). Lightweight ferrocement open web joist as low cost roofing element. Structures \& Architecture. ICSA - 1st International Conference on Structures \& Architecture, July 21-23, 2010 in Guimaraes, Portugal. Edited by Paulo J.S. Cruz., 449-450. DOI: $10.1201 / \mathrm{b} 10428-219$.

Alarcón, B., Aguado, A., Manga, R., \& Josa, A. (2011). A value function for assessing sustainability: Application to industrial buildings. Sustainability, 3(1): 35-50. doi: 10.3390/su3010035.

Balchin, P. \& Stewart, J. (2001). Social housing in Latin America: Opportunities for affordability in a region of housing need. Journal of Housing and the Built Environment, 16: 333-341.

Barros Cartelle, J. J., Lara, M., de la Cruz, \& del Caño, A. (2015). Assessing the global sustainability of different electricity generation systems. Energy, 89, 473-489. doi: 10.1016/j.energy. 2015.05.110

Barros, J. A., Oliveira, J. T., Bonaldo, E., \& Lourenço, P. B. (2006). Flexural behavior of reinforced masonry panels. American Concrete Institute.

Leitao, A. B., \& Ahern, J. (2002). Applying landscape ecological concepts and metrics in sustainable landscape planning. Landscape and urban planning, 59(2), 65-93.

Bredenoord, J. \& van Lindert, P. (2010). Pro-poor housing policies: Rethinking the potential of assisted self-help housing. Habitat international, vol. 34, 278-287.

Caballero, W. (2014). Forjados de bajo costo: análisis de la situación del área metropolitana de Bucaramanga (thesis).

Cansario, M. (2005). Sistema constructivo de paneles aligerados con poliestireno expandido y malla electrosoldada espacial: Estudio estructural y optimización. Universidad Politécnica de Cataluña, España. https://upcommons.upc.edu/handle/2117/93477.

Casanovas, M., Armengou, J. \& Ramos, G. (2014). Occupational risk index for assessment of risk in construction work by activity. Journal Construction Engineering Management, ASCE, vol. 140, Issue 1, 1-9. doi:10.1061/(ASCE) CO.1943-7862.0000785.

Castillo, A. A. T. \& Arnés Valencia, H. (2006). Innovación en la tecnología de losas tralizadas, reemplazando las joist filler blocks por losetas prefabricadas de ferrocemento (thesis).

Murillo, A., Ordóñez, A., Prado, A., Hernández, H., Galindo, M., Fuentes, H. \& Suárez, S. (2011). CDMB - Corporación Autónoma Regional para la Defensa de la Meseta de Bucaramanga. Modelo 
para el reconocimiento y tratamiento integral de los asentamientos precarios y barrios precaraios en el área metropolitana de Buaramanga fundamentado en los principios del desarrollo urbano sostenible. Convenio de Asocación Interinstitutional, no. 7018-16, 127.

Clarke, R. P. (2010). Study of full-scale elements of a ferrocement roof system for Caribbean application. Construction and Building Materials, 24(3), 221-229.

Cuadrado, J., Roji, E., San-José, J. T., \& Reyes, J. P. (2012). Sustainability index for industrial buildings. Proceedings of the Institution of Civil Engineers - Structures and Buildings, 165 (5): 245-253.

del Caño, A., Gómez, D., \& de la Cruz, M. P. (2012). Uncertainty analysis in the sustainable design of concrete structures: A probabilistic method. Construction and Building Materials, 37, 865-873. doi: 10.1016/ j.conbuildmat.2012.04.020.

del Caño, A., de la Cruz, M. P., Gómez, D., \& Pérez, M. (2016). Fuzzy method for analyzing uncertainty in the sustainable design of concrete structures. Journal of Civil Engineering and Management.

del Mistro, R. \& Hensher, D. A. (2009). Upgrading informal settlements in South Africa: Policy, rhetoric and what residents really value. Housing Studies, 24(3), 333-354.

de la Fuente, A., Blanco, A., Armengou, J., \& Aguado, A. (2017). Sustainability based-approach to determine the concrete type and reinforcement configuration of TBM tunnels linings. Case study: Extension line to Barcelona Airport T1. Tunnelling and Underground Space Technology, 61, 179-188.

de la Fuente, A., Pons, O., Josa, A., \& Aguado, A. (2016a). Multi-Criteria Decision Making in the sustainability assessment of sewerage pipe systems. Journal of Cleaner Production, 112, 4762-4770. doi: 10.1016 / j.jclepro.2015.07.002.

de la Fuente, A., Armengou, J., Pons, O., Aguado, A. (2016b) Multicriteria decision making model for assessing the sustainability index of wind-turbine system: Application to a new precast concrete alternative. Journal of Civil Engineering and Management. doi: 10.3846/ 13923730.2015 .1023347$.

Desayi, P., Viswanatha, C. S., \& Kanappan, S. (1982). Some studies on ferrocement roofing elements. Journal of Ferrocement - Bangkok, 12(3), 273-288.

Dhasarathan, A., Thenmozhi, R., \& Shree, M. S. D. Experimental study on the ductile characteristics of hybrid ferrocement slabs. A research work of Government College of Technology.

Gálligo, P.L. (2005). Un techo para vivir: tecnologías para viviendas de producción social en América Latina. Barcelona: Edicions UPC.

Gilbert, A. (2000). Financing self-help housing: Evidence from Bogotá, Colombia. International Planning Studies, 5(2), 165-190.

Gilbert, A., \& Ward, P. M. (1985). Housing, the state and the poor: Policy and practice in three Latin American cities (Vol. 50). Cambridge University Press.

Hago, A. W., Al-Jabri, K. S., Alnuaimi, A. S., Al-Moqbali, H., \& Al-Kubaisy, M. A. (2005). Ultimate and service behavior of ferrocement roof slab panels. Construction and Building Materials, 19(1), 31-37.

Pujadas, P., Pardo, F., Aguado-Renter, A., \& Aguado, A. (2017). MIVES multicriteria approach for the evaluation prioritization and selection of public investments projects. Case study of Barcelona city. Land Use Policy, 64, May, 29-37. doi:10.1016/

j.landusepol.2017.02.014. 
Hosseini, S. A., de la Fuente, A., \& Pons, O. (2016a). Multi-criteria decision-making method for assessing the sustainability of post-disaster temporary housing units technologies: A case study in Bam, 2003. Sustainable Cities and Society, 20, 38-51.

Hosseini, S. A., de la Fuente, A., \& Pons, O. (2016b). Multicriteria Decision-Making Method for Sustainable Site Location of Post-Disaster Temporary Housing in Urban Areas. Journal of Construction Engineering and Management, 04016036.

Imam, N., Maity, D., \& Kalita, U. C. (2002). An investigation on the shape of ferrocement roofing elements. Journal of ferrocement, 32(4), 271-286.

Jagannath, V., \& Chandra Shekar, U. (1989). Precast L-pan roof elements for low cost housing. Journal of ferrocement, 19(4), 353-361.

Li, Y. and Dong, W. (2012). The anti-seismic numerical simulation for a multi-storey frame with bamboo engineering materials. Advanced Materials Research. vols. 450-451, 1284-1287. doi:10.4028/www.scientific.net/AMR.450-451.1284.

Mattone, R. (1990). Ferrocement, prefabrication, self-help for low cost housing. Journal of ferrocement, 20(2), 143-148.

Melé, D., \& Armengou, J. (2016). Moral legitimacy in controversial projects and its relationship with social license to operate: A case study. Journal of Business Ethics. doi:10.1007/s10551-0152866-Z

Mora, C. \& Andrés, R. (2003). Diseño, fabricación y ensayo de vigas con perfil " $T$ ” de ferrocemento. Universidad Austral de Chile. Valdivia.

Obeng-Odoom, F. (2009). Has the Habitat for Humanity housing scheme achieved its goals? A Ghanaian case study. Journal of Housing and the Built Environment, 24:67-84. doi:10.1007/s10901-008-9128-7.

Ormazabal, G., Viñolas B., \& Aguado A. (2008). Enhancing value in crucial decisions: The line 9 of the Barcelona subway. Rev. Journal of Management in Engineering ASCE. 24(4), 265-273. doi:10.1061/(ASCE) 0742-597X(2008) 24:4(265).

Pardo-Bosch, F., \& Aguado, A. (2015). Investment priorities for the management of hydraulic structures. Structure and Infrastructure Engineering, 11 (10), 1338-1351. doi: 10.1080/ 15732479.2014.964267.

Pardo-Bosch, F., Aguado, A. (2016). Sustainability as the key to prioritize investments in public infrastructures. Environmental Impact Assessment Review, 60, 40-51. doi: 10.1016/j.eiar. 2016.03.007.

Pezo, J. L. V., \& Luís, J. (2004). Diseño, fabricación y ensayo de costaners de ferrocemento con sección omega y su comparación con costaneras de acerto tipo CA. Tesis. Universidad Austral de Chile. Valdivia.

Pinto Vergara, A. S., \& Arnés Valencia, H. (2005). Paneles prefabricados multiusos de ferrocemento (thesis).

Pons, O., \& Aguado, A. (2012). Integrated value model for sustainable assessment applied to technologies used to build schools in Catalonia, Spain. Building and Environment, 53, 49-58. doi:10.1016/ j.buildenv.2012.01.007.

Pons, O., \& de la Fuente, A. (2013). Integrated sustainability assessment method applied to structural concrete columns. Construction and Building Materials, 49, 882-893. doi: 10.1016/j.conbuildmat. 2013.09.009.

Pons, O., de la Fuente, A. \& Aguado, A. (2016). The use of MIVES as a sustainability assessment MCDM method for architecture and civil engineering applications. Sustainability, vol. 8, Issue 5, $\mathrm{n}^{\circ} .460,15$. doi:10.3390/ su8050460.

Rinku, T. \& Devit, V. (2009). Low cost housing. ACSGE-2009, Oct 25-27, BITS Pilani, India. 
Saaty, T. L. (1980) Analytical hierarchy process planning, priority setting, resource allocation. RWS publication, Pittsburg PA: University of Pittsburgh.

Saaty, T. L. (1988). What is the analytic hierarchy process?. Mathematical models for decision support, 109-121. Springer Berlin Heidelberg.

San-José J. T., Losada R., Cuadrado J., \& Garrucho I. (2007). Approach to the quantification of the sustainable value in industrial buildings. Building and Environment, 42 (11), 3916-3923. doi:10.1016/j.buildenv.2006.11.013.

San-José, J. T., \& Garrucho, I. (2010). A system approach to the environmental analysis of industrial buildings. Building and Environment, 45(3): 673-683. doi:10.1016/j.buildenv. 2009.08.012.

Santibáñez, R. A. U., \& Andrés, R. (2004). Diseño, fabricación y ensayo de vigas con perfil doble "T" de ferrocemento. Universidad Austral de Chile. Valdivia.

Thanoon, W. A., Yardim, Y., Jaafar, M. S., \& Noorzaei, J. (2010). Structural behaviour of ferrocement-brick composite floor slab panel. Construction and Building Materials, 24(11), 2224-2230.

Van Kamp, I., Leidelmeijer, K., Marsman, G., \& De Hollander, A. (2003). Urban environmental quality and human well-being: Towards a conceptual framework and demarcation of concepts; a literature study. Landscape and urban planning, 65(1), 5-18.

Waliuddin, A. M., \& Ismail, M. S. (1995). An economical and lightweight ferrocement roofing system. Journal of ferrocement, 25(2), 129-135.

Ward, P. M., Huerta, E. R. J., Grajeda, E., \& Velázquez, C. U. (2011). Self-help housing policies for second generation inheritance and succession of "The House that Mum \& Dad Built". Habitat International, 35(3), 467-485.

Yardim, W. T., Jafaar, M. S., Noorzaei, J., Khan, S. R., \& Kamal, N. M. (2008). Performance Precast Ferrocement Panel for Composite Masonry Slab System. 


\section{APPENDIX 1}

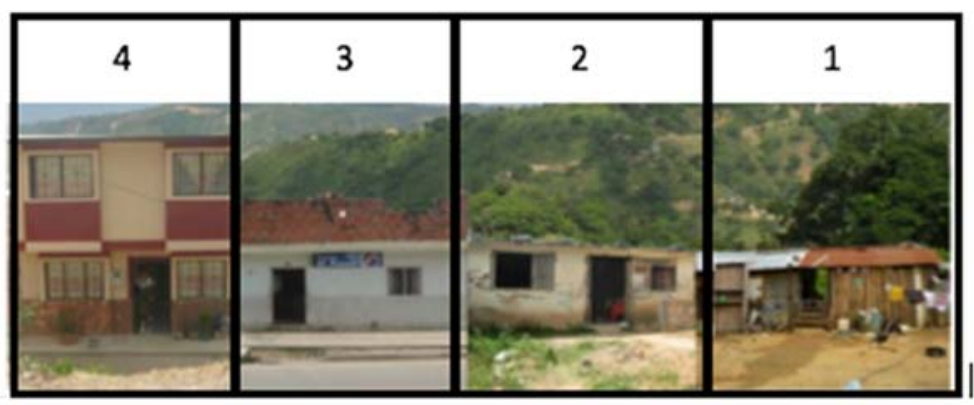

Typical evolution of housing in informal settlements such as that of Bucaramanga. Stage 1: house build with cardboard, wood and plastic. Stage 2: house built with bricks and wood. Stage 3: improvement of the house structure, in bricks. Stage 4: house expansion by building a second floor.

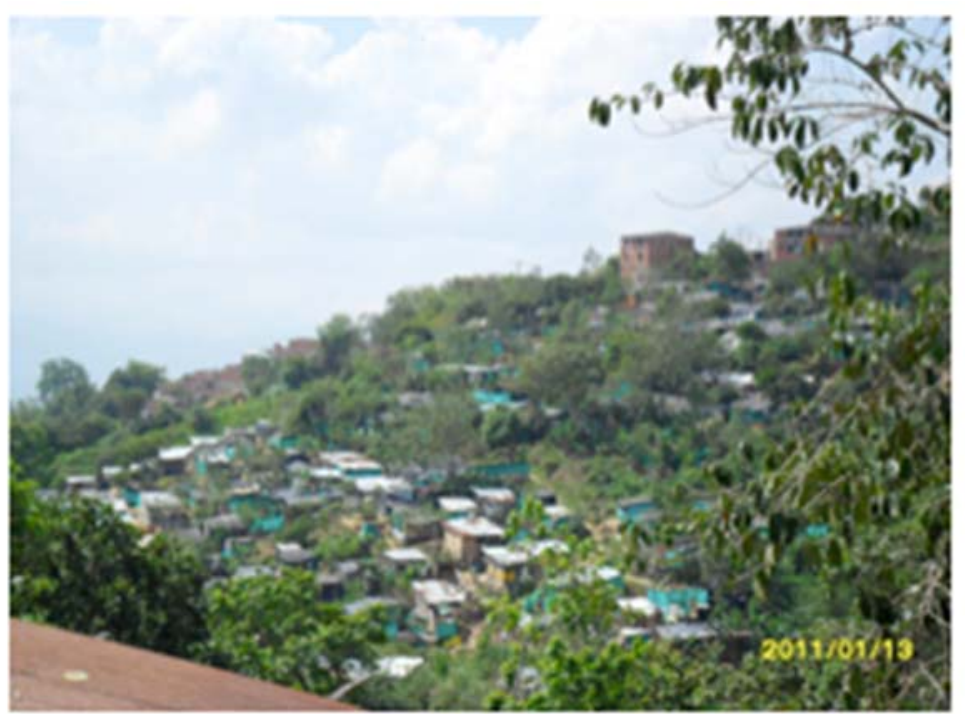

Informal settlement of Asohelechales, Floridablanca

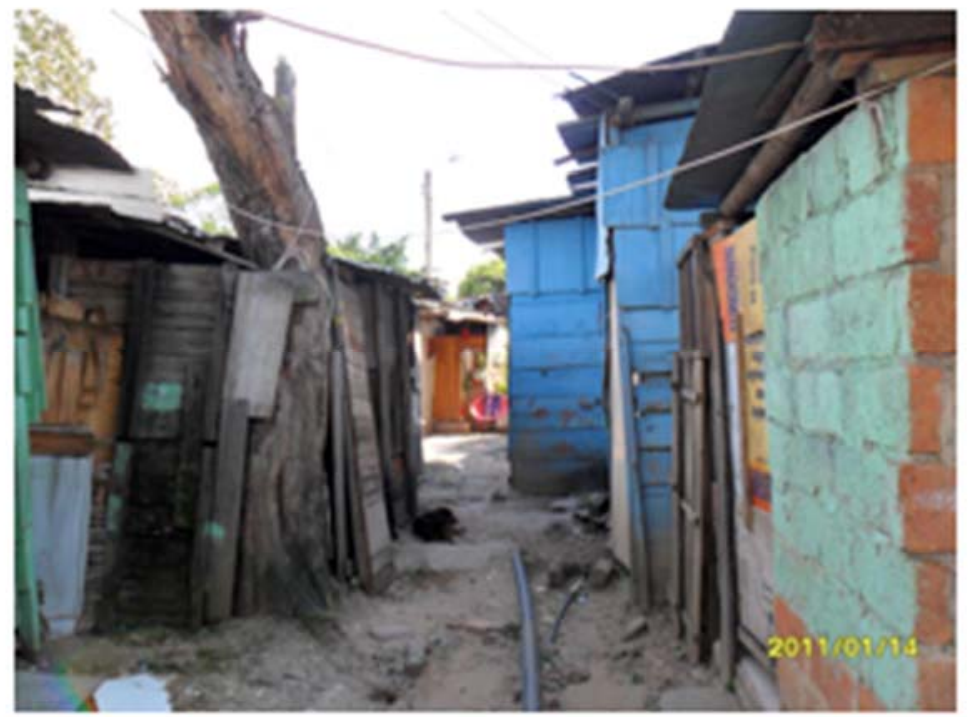

Houses in the informal settlement of Bucaramanga 


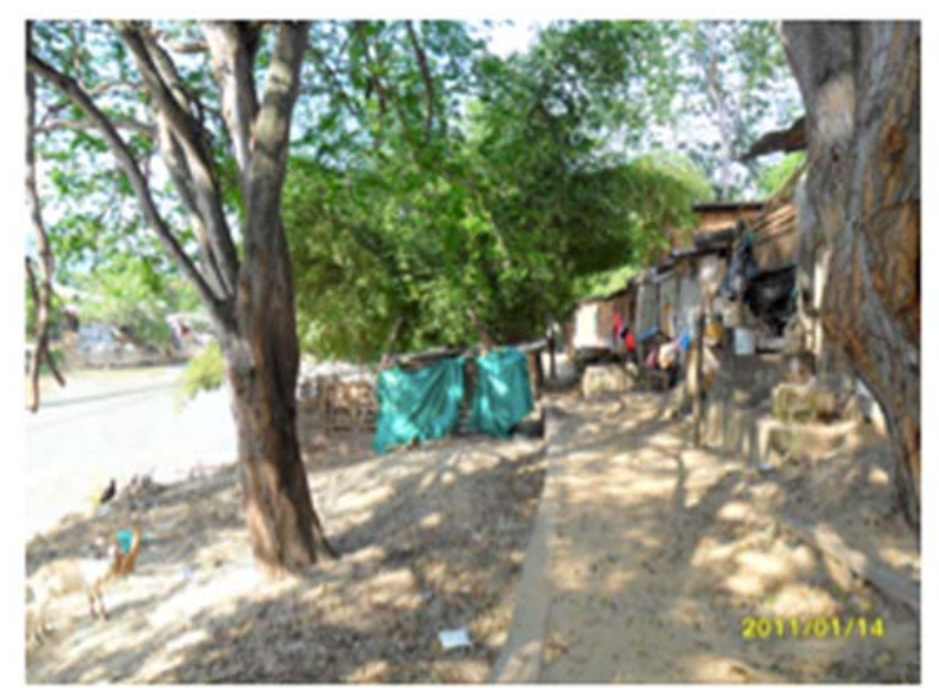

Houses in the informal settlement of Mi Riconcito, Girón 